\title{
Hanoi Consumers' Attitudes Toward Direct Marketing
}

\author{
Thanh Thi Hoang \\ University of Transport Technology, 54 Trieu Khuc, Thanh Xuan, Ha Noi, Viet Nam
}

The research is financed by University of Transport Technology.

\section{Abstract}

In an increasingly competitive environment, retailers must understand consumers' behaviors in order to can build effective communication strategies, to maintain loyal customers. Attitudes are fundamental factors that have great influences on consumers' behaviors. In order to change a part of consumers' attitudes toward direct marketing, it is necessary to analyze the components that influence the attitudes. On the basis of the synthesis of theory and quantitative research, the result shows that five factors influence on consumers' attitude towards with direct marketing. They are informativity, persuasion, harassment, convenience, and permission. Convenience is the greatest factor that impacts on consumer attitudes toward direct marketing. Harassment have the opposite effect on consumer attitudes toward direct marketing.

Keywords: Consumer Attitude, Direct Marketing

DOI: $10.7176 / \mathrm{EJBM} / 12-30-03$

Publication date:October $31^{\text {st }} 2020$

\section{Introduction}

Direct marketing is an important communication tool for retailers. The new age of digital technology creates effective and low - cost tools of direct communication. However, consumers feeling annoyed by receiving too many direct ads, fearing that personal information is unsecure, or that part of consumers don't trust advertising and direct shopping. Researches show that $20 \%$ of customer loyalty leads to $80 \%$ of the profit for businesses, and a $5 \%$ increase in customer loyalty will increase the customer lifetime value by $22 \%$ to $37 \%$ (Gupta and Lehmann, 2003). Understanding customer behavior is the direct and most important basis for developing effective marketing programs (Truong Dinh Chien, 2013). Both theoretical and practical studies show that consumers' attitudes are the foundation for their behaviors ( $\mathrm{Li}$ et al., 2017). In the internet environment, customer loyalty will be a particularly important factor in the success of retailers (H. Robert Wientzen, 2000). Therefore, research on consumer attitudes is one of the important prerequisites for promoting direct marketing activities. Consumers' acceptance and positive attitudes are decisive factors for retailers to build appropriate direct marketing programs and perform effective direct marketing activities.

\section{Literature Review}

\subsection{Consumers' Attitudes}

Attitude is one of four basic factors that greatly influence consumer behavior. Attitudes are understood as assessments, emotions and relatively consistent actions on a certain thing, phenomenon or idea (Tran Minh Dao, 2018). These assessments are difficult to change because they lead customers acting in a fairly stable thinking and acting habits. To change a certain attitude, it is necessary to analyze and influence the components that affect the attitude.

A person's actual behavior is determined mainly by the individual's intentions to perform that act. This intention is influenced by two factors: attitude towards subjective behavior and norms (Fishbein and Ajzen, 1975; Davis, Bagozzi, \& Warshaw, 1989). Behavior-oriented attitudes are determined by beliefs about product attributes, while subjective factors are influenced by perceptions and beliefs of reference groups. However, this paradigm is inexplicable when the individual making the decision isn't under the control of reasons (Ajzen, 1991). The model's predictive power is also limited when the actual behaviors and intentions are highly correlated (Yousafzai, Foxall, \& Pallister, 2010). Based on the limitations of the theory of rational action, the model of planned behavior (Ajzen, 1991) has added an element of cognitive behavior control. There are three factors that affect your intention to perform a certain behavior. They are attitudes towards behaviors, subjective norms and cognitive behavioral control. This is an extended model of rational behavioral theory, so the predictability of the model is still limited when the actual intent and behavior are highly correlated. This model omits some factors that can increase predictability such as personal rules and emotional impact (Yousafzai, 2010).

Based on the theoretical rational action model - TRA, Davis (1989) provided a model that explains an individual's behavior in relation to computer use - the Technology Acceptance Model (Technology Acceptance Model - TAM). Actual behavior is determined mainly by behavioral intent. In which behavioral intention is determined by the attitude towards the behavior and the realization of usefulness. In addition, in this model, attitudes towards behavior are influenced by environmental factors such as experience, knowledge, training levels, and technological processes. Developed from TAM, Fortes \& Rita (2016) built an information security model. 
Intention of using product is determined by attitudes toward service, perceived ease of use, and cognitive behavior control. In which, service attitude is determined by trust, perceived risk, perceived usefulness, and perceived ease of use.

In the study of consumer attitudes towards direct marketing and buying intent, Akhter and Durvasula (1991) consumers' attitudes toward direct marketing is what consumers think about three elements of direct marketing (direct marketers/ businessmen, direct marketing channels, and feedback channels). Positive thoughts on at least two factors lead to more favorable response toward direct marketing. Researches show that attitudes towards media and feedback channels are more important than attitudes towards businesses in determining consumers' accepting behavior of direct marketing. Receiving too much direct mails leads to negative attitudes towards direct marketing (Akaah et al., 1995). Consumers' experiences in direct marketing activities will determine their attitudes toward direct marketing. Good experiences will lead to more positive attitude.

\subsection{Research model and Hypotheses}

Inheriting the previous research models and the reality of direct marketing activities in Hanoi city, the research hypotheses are proposed as following:

Hypothesis H1: Informativity has a positive effect on consumers' attitudes toward direct marketing.

Informativity of a communication program is informing about product features to the consumer in order to they can select and shopping (Ducoffe, 1996). One of the key tasks of communication activities is to make customers remember the brand as well as recognize and distinguish the company's products and services from competitors' products (Hair et al., 2000). Therefore, marketing communications should focus on providing informations about new products, technology innovations, prices, and promotions (Kotler and Keller, 2006). The informative value will have a positive effect on consumers' attitudes. Therefore, the content should be concise, simple, accurate and suitable for the targeted customer.

Hypothesis H2: Persuasion has a positive effect on consumers' attitudes toward direct marketing.

Persuasion is one of major factors influencing attitudes toward communication messages (Brackett and Carr, 2001). Persuasion in marketing comunication activities is how consumers consider honest or trustworthy of a marketing comunication program (Siau and Shen, 2003). The persuasion in an ad determines perception of listeners. Studies have consistently shown that persuation has a positive effect on consumer attitudes toward marketing communications (Aizen, 1991; Goldsmith et al., 2000; Bracker and Carr, 2001; Tsang, 2004).

Hypothesis H3: Harassment has a negative effect on consumers' attitudes toward direct marketing.

The harassment of marketing activities is that the marketing programs are used to cause annoyance and insult to consumers (Ducoffe, 1996). Harassment have a negative impact on the value of an advertisement. A program deemed annoying will lead to underestimating its value (Brackett and Carr, 2001). This leads to negative consumer behavior towards the message received. They may not be interested, viewed, ignored or rejected. Because every day you receive many promotion letters, ad messages or calls that make consumers feel uncomfortable (Akhter and Durvasula, 1991; Shena Mitchell, 2003; Barwise, 2005). In addition, privacy and confidentiality are also issues that businesses need to pay attention today to avoid causing annoyance to consumers (Maynard and Taylor, 1996; Galasint et al., 2018).

Hypothesis H4: Convenience has a positive effect on consumers' attitudes toward direct marketing.

Benefits from direct marketing activities make consumers more satisfied than shopping at the store (Maynard and Taylor, 1996). There are some reasons why consumers like direct marketing. For example: afraid to shop, prefer anonymity when shopping, want to own goods that are different from others, or want to buy goods that are not available at the store. Researches show that consumers appreciate the ability of direct marketing to provide feedback opportunities to retailers and serve a useful purpose. In technology environment, online communication channels provide the convenience of low transaction cost to customers (Lal and Sarvary, 1999; Chintagunta et al., 2012). As a result, consumers prefer to use digital channels for their product search and an increasing number of consumers prefer to use technology for shopping (Nakano and Kondo, 2018).

Hypothesis H5: Permission has a positive effect on consumers' attitudes toward direct marketing.

Consumers' consent will negatively affect their attitudes toward marketing if they do not give permission for that marketing activity (Tsang et al., 2004). For permission-based advertising, information about specific products and services is sent to the authorized consumer. Consumers voluntarily participate in corporate communications by accepting advertising information. Therefore, the response rate of accepted messages is higher than that of traditional message promotion (Muk, 2007). 
The proposed research model is as follows:

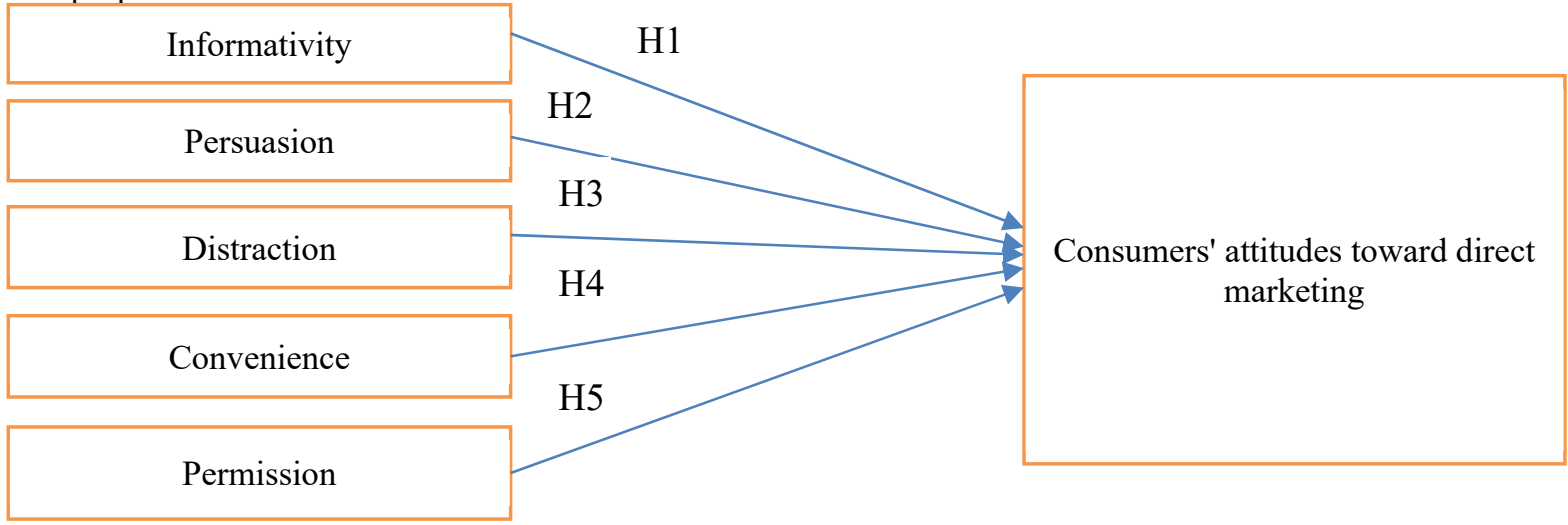

Figure 1: Proposed research model

\section{Research methodology}

Survey is implemented from March 1 to March 15, 2020 through direct polls and google forms by developing sample size germs (Nguyen Dinh Tho, 2011). Questionnaires are sent directly and emailed links to candidates in the author's friends list, colleagues and students at the University of Transport Technology living in Ha Noi city. In addition to asking candidates for answers, the author suggests candidates send questionnaires and forward links to other candidates in their relationships. The results of synthesizing the survey by both forms until March 15 , 2020 reached 310 votes, the number of valid votes is 310 . In which, 247 direct survey questions (the number of votes is 247 , the number of votes is collected 247 valid votes), and 63 valid online surveys.

The collected data is processed by SPSS 25.0 through the following steps: descriptive statistics, assessment of the reliability of the scale, analysis of discovery factors EFA, correlation coefficient analysis and regression.

\section{Research Results}

\subsection{The sample statistics}

Characteristics of the observed sample are shown as follows: $32.58 \%$ of respondents are male and $67.42 \%$ of respondents are female. In terms of age, mainly the survey participants are young people, the number of people under 30 years old accounts for $83.87 \%$.

\subsection{Scale test}

The results of evaluating the reliability of the scale by Cronbach's Alpha showed that all scales had reliability greater than 0.6 and total variable correlation coefficient greater than 0.3. All scales satisfy the conditions to analyze discovery factors EFA. The reliability of the scales is summed up in the table below.

Table 1: Scale test results

\begin{tabular}{|c|c|c|c|c|c|}
\hline No. & Variable name & Symbols & $\begin{array}{c}\text { Number of } \\
\text { Items }\end{array}$ & $\begin{array}{c}\text { Cronbach's } \\
\text { Alpha }\end{array}$ & $\begin{array}{c}\text { Smallest total variable } \\
\text { correlation coefficient }\end{array}$ \\
\hline 1 & Informationality & INF & 4 & 0.787 & 0.541 \\
\hline 2 & Persuasion & TC & 4 & 0.888 & 0.667 \\
\hline 3 & Distraction & PN & 4 & 0.910 & 0.708 \\
\hline 4 & Convenience & TI & 6 & 0.844 & 0.552 \\
\hline 5 & Permission & CP & 3 & 0.663 & 0.339 \\
\hline 6 & $\begin{array}{c}\text { Attitude to direct } \\
\text { marketing }\end{array}$ & TĐ & 4 & 0.884 & 0.514 \\
\hline
\end{tabular}

The reliability test of the scale by Cronbach's Alpha shows that the scales measured with reliability greater than 0.6 and total variable correlation coefficient greater than 0.3 . All scales satisfy the conditions to analyze discovery factors EFA.

\subsection{Explore factor analysis EFA}

Factor analysis was performed with Principle Component extraction, Varimax rotation for the dependent observed variable. The results show that the coefficient $\mathrm{KMO}=0.868$ (meet the condition $>0.5$ ). Significance level and Barlett test $=0.000$ (meet condition $<0.05$ ) shows that EFA analysis is suitable. The total extracted variance is $56.5709 \%$; and factor load factors are greater than 0.5 , so it is satisfactory. The official scale after treating EFA includes 21 observed variables as proposed. 
Table 2. The results of EFA analysis

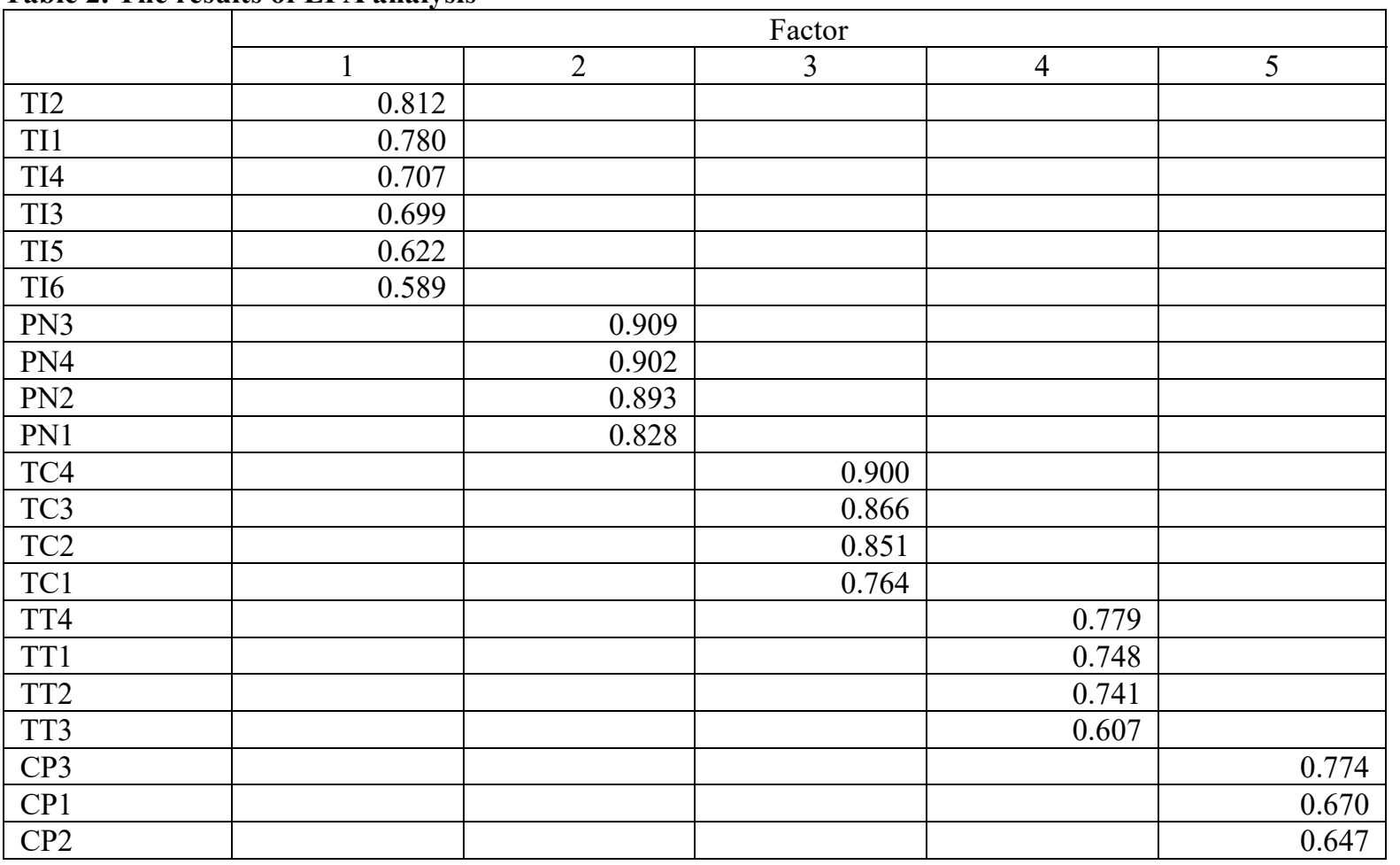

Analysis in Pearson's correlation matrix showed that Correlation coefficients are statistically significant (Sig. $<0.01)$. Therefore, all variables will be used in regression analysis.

\subsection{Regression Analysis}

Table 3. Results of statistical values of factors affecting consumer attitudes toward direct marketing activities

\begin{tabular}{|l|c|c|c|r|r|}
\hline & \multicolumn{5}{|c|}{ Summary model } \\
\hline Model & R & Rsquared & Adjusted R squared & Std. Error of the Estimate & Durbin - Watso \\
\hline 1 & 0.759 & 0.577 & 0.570 & 0.55813 & 2.092 \\
\hline $\begin{array}{l}\text { a. Predictors: (Constant), INFOMATIVITY, PERSUASION, DISTRACTION, } \\
\text { PERMISSION }\end{array}$ \\
b. Dependent Variable: ATTITUDE \\
\hline
\end{tabular}

$\mathrm{R}$ - squared reflects the influence of the independent variables on the variation of the dependent variable, in this case 5 factors (Infomativity, Persuasion, Distraction, Convenience, Permission) $57.0 \%$ influence on changes in consumers' attitudes towards direct marketing. Factors other than the model and random error affected $43 \%$ of the attitude factor. The Durbin-Watson coefficient is 2.092, in the range from 1.5 to 2.5 , so there is no first order sequence autocorrelation.

In order to check whether this regression model is suitable for the collected data set and has application significance, the author continues to test the model's suitability through ANOVA test as follows:

Table 4. Testing the appropriateness of the model (ANOVA)

\begin{tabular}{|l|l|r|r|r|r|r|}
\hline \multicolumn{2}{|l|}{ Model } & Sum of Squares & Df & Mean Square & F & Sig. \\
\hline \multirow{3}{*}{1} & Regression & 128.970 & 5 & 25.794 & 82.803 & $0.000^{\mathrm{b}}$ \\
\cline { 2 - 7 } & Residual & 94.699 & 304 & 0.312 & & \\
\cline { 2 - 7 } & Total & 223.699 & 309 & & \\
\hline
\end{tabular}

Sig tested $\mathrm{F}=0.000<0.05$, so the regression model assesses the impact level of 5 factors (allowable, annoying interference, trustworthiness, information, utility) to consumer attitudes towards direct marketing activities.

The model's F-statistic has the value Sig. $=0.000<0.05$ shows that the model is consistent with the data set and can be deduced overall. VIF coefficients are all less than 2, so there is no multicollinearity phenomenon between the components that does not appear in the research model.

The regression results show that the influence of 5 factors on consumer attitudes towards direct marketing 
activities is shown in the following table:

Table 5. Multiple regression results with partial regression coefficients

\begin{tabular}{|c|c|c|c|c|c|c|c|c|}
\hline \multicolumn{9}{|c|}{ Coefficients $^{\mathrm{a}}$} \\
\hline & \multirow[b]{2}{*}{ Model } & \multicolumn{2}{|c|}{$\begin{array}{l}\text { Unstandardized } \\
\text { Coeffcients }\end{array}$} & \multirow{2}{*}{$\begin{array}{c}\begin{array}{c}\text { Standardized } \\
\text { Coefficients }\end{array} \\
\text { Beta } \\
\end{array}$} & \multirow[t]{2}{*}{$\mathrm{T}$} & \multirow[t]{2}{*}{ Sig. } & \multicolumn{2}{|c|}{ Multi-statistics } \\
\hline & & B & Std. Error & & & & Tolerance & VIF \\
\hline 1 & (Constant) & 0.015 & 0.214 & & 0.071 & 0.944 & & \\
\hline & INFORMATION & 0.265 & 0.050 & 0.243 & 5250 & 0.000 & 0.653 & 1.532 \\
\hline & RELIANCE & 0.137 & 0.035 & 0.157 & 3857 & 0.000 & 0.840 & 1.190 \\
\hline & DISTRACTION & -0.076 & 0.027 & -0.105 & -2792 & 0.006 & 0.985 & 1.015 \\
\hline & CONVENIENCE & 0.412 & 0.052 & 0.378 & 7927 & 0.000 & 0.613 & 1.631 \\
\hline & PERMISSION & 0.239 & 0.049 & 0.218 & 4890 & 0.000 & 0.700 & 1.429 \\
\hline
\end{tabular}

The regression model is written as:

$$
\mathrm{Y}=0.015+0.243 \mathrm{X}_{1}+0.157 \mathrm{X}_{2}-0.105 \mathrm{X}_{3}+0.378 \mathrm{X}_{4}+0.218 \mathrm{X}_{5}+\mathrm{E}
$$

Where: $\mathrm{Y}$ is the consumer attitude towards with direct marketing.

$\mathrm{X}_{1}$ : INFORMATION; $\mathrm{X}_{2}$ : RELIANCE; $\mathrm{X}_{3}$ : DISTRACTION; $\mathrm{X}_{4}$ : CONVENIENCE; $\mathrm{X}_{5}$ : PERMISSION; E: RESIDUAL

Histogram normalized residual frequency chart with very small mean close to 0 (Mean $=-1.89 \mathrm{E}-15)$ and standard deviation close to 1 (0.992). Thus, the normal distribution of the remainder is not violated.

\section{Conclusions and recommendations topic}

The research has identified 5 factors affecting consumer attitudes towards direct marketing activities of retail businesses in Hanoi City with the impact level. The impact of each factor is as follows:

The utilities that consumers get from direct marketing activities of the retail business have the greatest impact on their attitude (regression coefficient is 0.378). Direct marketing creates convenience in terms of time, place and flexible means of communication between the retail business and consumers. These are the advantages of direct marketing that are highly valued by consumers in comparison to conventional means of communication (such as advertising, public relations, promotions), and compared with the method of buying in a store. Retailers need to enhance relevant direct marketing content and support customers in direct ordering methods.

Authorization is the second most important factor determining consumer attitudes toward direct marketing, with a regression coefficient of 0.218 . In the face of consumers often receiving catalogs, text messages, phone calls, and emails about products they are not interested in. Consumers now pay more attention to methods of refining, limiting advertising information, and limiting advertising businesses. This requires retail businesses to pay more attention to customer behavior research, target market segmentation in accordance with their direct marketing strategy.

The informativeness of the direct marketing communication message has an influence on the consumer's attitude towards the direct marketing activities of the business, with a regression coefficient of 0.243 . Information sent to consumers must be suitable with the right audience, presented in an interesting way to attract and keep customers in mind, and at the same time bring useful value to them.

Confidence has a positive impact on consumer assessments of retail businesses' direct marketing with a regression coefficient of 0.157 . The trust of consumers can be obtained by personal experience or recommended by acquaintances. Therefore, retail businesses need to find ways to communicate regularly, create closeness and trust of consumers with their products and brands.

Distractions have the opposite effect on consumer attitudes (regression coefficient - 0.15). Consumers have not really good attitudes towards direct marketing activities of retail businesses. They do not want to passively receive advertising information directly. Having the choice of information, time, method and enterprises to send the message will make consumers not bothered by the information of the business.

This study has identified a number of factors affecting consumer attitudes towards direct marketing of retail businesses. However, the study was only conducted in Hanoi City, with convenient sampling. The sample size is still small compared to the total consumers in the city. Therefore, the representativeness of the research sample is limited. The study has not mentioned other aspects that can affect consumer attitudes towards direct marketing such as personalization, interactivity, demographic characteristics, direct buying experience, ... These are also suggestions for the next research.

\section{References}

Ajzen I. (1991), The theory of planned behavior, Organizational Behavior and Human Decision Processes, 50,179

$$
-211 .
$$


Brackett LK, Carr BN (2001), Cyberspace Advertising vs. Other Media: Consumer vs. Mature Student Attitudes, Journal of Advertising Research, No.41, pp 23 - 32.

Chintagunta, Pradeep K., Junhong Chu, and Javier Cebollada (2012), Quantifying Transaction Costs in Online / Off-line Grocery Channel Choice, Marketing Science, 31 ,1, 96-114.

Davis, Bagozzi, Warshaw, (1989), Perceived usefulness, perceived ease of use and user acceptance of information technology, MIS Quarterly, 13 (3), 319-339.

Ducoffe R H. (1996), Advertising Value and Advertising on the Web, Journal of Advertising Research, No.17, pp $1-18$.

Fishbein, M., \& Ajzen, I. (1975), Belief, attitude, intention and behavior: An introduction to theory and research, Addison-Wesley, Reading, MA.

Fortest, N. \& Rita, P. (2016), "Privacy concerns and online purchasing behavior: Towards an integrated model", European Research on Management and Business Economics, 22 (3), 167-176.

Goldsmith RE, Lafferty BA, Newell AJ (2000), The Impact of Corporate Credibility and Celebrity Credibillity on Consumer Reaction to Advertisment and Brand, Journal of Advertising, Vol.29, pp 43 - 54.

Gupta, S., \& Lehmann, DR (2003). Customers as assets. Journal of interactive Marketing, 17 (1), 9-24.

H. Robert Wientz (2000), What is the Internet's Impact on Direct Marketing Today and Tomorrow? The Journal of Direct Marketing.

Hair, JF, Black, WC, Babin, BJ, Anderson, RE \& Tatham, RL (2006), Mutilvariate data analysis, 6th ed., Upper Saddle River NJ, Prentice -Hall.

Ishmael P.Akaah, Pradeep K. Korgaonkar, Daulatram Lund (1995), Direct marketing attitudes, Journal of Business Research, Volume 34, Issue 3, November, Pages 211-219.

Kotler, P., Keller, LK (2006). Marketing Management, 12th Ed, New Delhi: Prentice Hal.

Lana KB, Benjamin NC (2001), Cyberspace advertising vs. other media: consumer vs. mature student attitudes, Journal of advertising research, 23-34.

Li, Y., Hu, C., Huang, C., \& Duan, L (2017). The concept of smart tourism in the context of tourism information services. Tourism Management, 58, 293- 300.

Michael L. Maynard, Charles R. Taylor, A Comparative Analysis of Japanese and US Attitudes toward Direct Marketing, Journal of Direct Marketing, Volume 10, Number 1, 1996.

Mitchell, S. (2003), The new age of direct marketing, Journal of Database Marketing \& Customer Strategy Management, 10 (3), 219-229.

Muk, Alexander. (2007), Consumers' Intentions to Opt in to SMS Advertising: A Cross-National Study of Young Americans and Koreans, International Journal of Advertising, 26, 2, pp.177- 198.

Nakano, S., Kondo, FN (2018), Customer segmentation with purchase channels and media touchpoints using single source panel data. J. Retail. Consum. Serv. 41, 142-152.

Sareeya Galasintu, Susom Supanit, (2018), The issue of direct sales and direct marketing law and enforcement in Thailand: A comparative study of the relevant UK and Malaysia laws, Journal of Social Sciences.

Siau, K., Shen, Z. (2003), "Building Customer Trust in Mobile Commerce”, Journal of Business Research, Vol. 46, Issue. 4, pp. 91-96.

Syed H. Akhter, Srinivas Durasula, Consumers' Attitudes Toward Direct Marketing and Purchase Intentions, Journal of Direct Marketing, Volume 5, Number 3, 1991

Trần Minh Đạo (2018), Giáo trình marketing căn bản, NXB Kinh tế quốc dân.

Trương Đình Chiến (2013), Truyền thông Marketing tích hợp, NXB ĐH Kinh tế quốc dân.

Tsang MM, Ho SC, Liang TP (2004), Consumer Attitudes Toward Mobile Advertising: An Empirical Study, International Journal of Electrionic Commerce, No.8, pp 65 - 78

Yousafzai, SY, Foxall, GR, \& Pallister, JG (2010), Explaining internet banking behavior: Theory of reasoned action, theory of planned behavior, or technology acceptance model, Journal of Applied Social Psychology, 40(5), 1172-1202. 